\title{
ANALISA PENGARUH PEMILIHAN TEKNOLOGI TERHADAP STRATEGI KOMPETITIF PADA SEJUMLAH PERUSAHAAN INDUSTRI KOMPONEN ELEKTRONIKA DI BATAM
}

\author{
Suwarno \\ Universitas Internasional Batam, Jln. Gajah Mada, Sei Ladi, Tiban Indah, Sekupang, Batam, Kepulauan Riau 29442.
}

\section{INFORMASI ARTIKEL}

Diterima Redaksi: 1 Februari 2020

Diterbitkan Online: 30 Maret 2020

\section{KATA KUNCI}

Innovation, Research And

Development, Technology Resources,

Technology Exploitation And

Investment, Competitive Strategy

KORESPONDENSI

E-mail: suwarno.liang@uib.ac.id

\section{A B S T T R A C $\mathbf{C}$}

Technology has become a major part in all areas of life, covering the lives of individuals and communities. Especially in the city of Batam, as an industrial city ranging from the electronics industry to shipyards. In Batam city, there are 129 electronics component industry companies. Technological developments continue to change, therefore electronics component industry companies always adopt the latest technology to support business processes. The choice of technology has become part of a competitive strategy that can keep the company sustain. In the selection of this technology, there are four important variables can be utilized by the company in a manner, they are: innovation, research and development, technology resources, technology exploitation and investment. As the results of the study, these four variables significantly influence $66.9 \%$ of competitive strategy in a number of electronics companies in the city of Batam.

\section{Latar Belakang}

Pertumbuhan produk elektronik di dunia saat ini cukup tinggi seperti halnya pendapatan industri elektronik konsumer pada tahun 2013 mencapai US\$ 207 miliar, namun Asosiasi Elektronik Konsumer (CEA, Consumer Electronics Association) yang berbasis di Amerika memprediksikan bahwa pada tahun 2014 ini akan mencapai angka tertinggi dibanding tahun-tahun sebelumnya, yaitu meningkat 2 persen atau mencapai angka US\$211,3 miliar, dan untuk tahun 2015 akan elektronik konsumer akan mencapai pertumbuhan 1,2 persen dengan total US\$ 214 (Vivanews.co.id). Adapun kategori produk elektronik yang memberikan kontribusi terbesar adalah perangkat mobile khususnya smartphone dan tablet, dan produk TV LCD panel datar. "Produk yang berkontribusi besar terhadap pendapatan elektronik konsumer adalah dua perangkat itu, ditambah TV LCD panel datar. Ketiganya bisa ditemukan di hampir semua rumah di dunia," ujar Direktur dan Analis Industri CEA, Steve Koenig. Penjualan produk smartphone dan tablet diprediksikan akan memberikan 35,1 persen dari total pendapatan elektronik konsumer di tahun 2014, yaitu penjualan smartphone akan menghasilkan pendapatan US\$46 miliar di tahun 2014 atau naik 7 persen dibanding tahun 2013 yang hanya US\$ 43 miliar, dan penjualan tablet akan mencapai US\$25,6 miliar (Vivanews.co.id).

Seperti yang diutarakan oleh Gartner, Inc. bahwa sejumlah analis menilai bahwa terdapat 10 macam jenis tren teknologi yang harus dimasukkan sebagai factor dalam proses perencanaan strategis yaitu perangkat mobile, program aplikasi mobile, internet, teknologi Hybrid Cloud, Cloud/Client Architecture, Personal Cloud, Software Defined Anything (SDx), Web-Scale IT, Smart Machines, dan pencetakan tiga dimensi (Gartner.com). Sebagai contoh kita dapat menjumpai pada sejumlah produk elektronik televisi yang telah dilengkapi dengan fasilitas internet.

Salah satu perusahaan yang memproduksi komponen elektronika adalah Foxconn, merupakan perusahaan terbesar yang memproduksi komponen elektronika untuk dipasarkan di seluruh dunia dan 
menjadi mitra perusahaan elektronik besar di dunia, seperti Intel meminta Foxconn untuk mengembangkan motherboard, dan Apple mempercayakan komponen elektronika diproduksi oleh Foxconn. Pada tahun 2012, Sharp Corporation juga memakai Foxconn sebagai pengembang manufaktur produk seperti TV LCD (Ekonomi.inilah.com).

Sedangkan di Indonesia, pertumbuhan penjualan produk elektronik didukung oleh barang perlengkapan rumah tangga, televisi, kulkas, mesin cuci dan air conditioner $(A C)$, yang mana angka prediksi peningkatan target penjualan tahun 2014 mencapai $10 \%$ untuk televisi, dan $20 \%$ untuk $A C$ dari tahun 2013. Menurut Ali Soebroto Oentaryo, Ketua Gabungan Pengusaha Elektronik (Gabel) mengatakan bahwa rumah tangga Indonesia saat ini mengalami pergeseran kebutuhannya, televisi dan kulkas sudah menjadi kebutuhan primer, dan $A C$ tidak lagi menjadi kebutuhan tersier (gosocio.co.id). PT. Sat Nusapersada Tbk dan PT. Tata Sarana Mandiri di Batam telah membuat produk smartphone $4 G$ yang pertama di Indonesia, sebagai salah satu produk elektronik yang canggih dengan didukung oleh Qualcomm Snapdragon 400 chipset, menggunakan prosesor Quad Core 1.2 $\mathrm{GHz}$, RAM $1 \mathrm{~GB}$, media penyimpanan berkapasitas $8 \mathrm{~GB}$, kamera $8 \mathrm{MP}$, dan dual SIM card yang dirancang khusus untuk kebutuhan masyarakat di Indonesia (Detik.com).

Dengan melihat perubahan kebutuhan masyarakat maka disinilah letak peranan pentingnya kemajuan teknologi dan ilmu pengetahuan sehingga menyebabkan perusahaan elektronik terpacu untuk menghasilkan produk yang kreatif dan inovatif sehingga bisa diterima di tengah masyarakat, dan mampu memberikan keunggulan kompetitif. Oleh karenanya diperlukan penyusunan strategi teknologi guna memilih teknologi yang tepat yang dapat memberikan keunggulan kompetitif. Strategi Teknologi sangat penting bagi perusahaan, tetapi sedikit penelitian empiris yang telah dilakukan tentang dampak pilihan teknologi pada strategi kompetitif..

\section{Kajian Literatur}

\section{A. Keunggulan Kompetitif}

Keunggulan kompetitif adalah ukuran dari kompetensi perusahaan dan kinerja terhadap faktorfaktor yang berlaku di lingkungan eksternal perusahaan. Keunggulan kompetitif didefinisikan sebagai kemampuan sebuah bisnis untuk memperoleh keuntungan abnormal dalam industri yang kompetitif didasarkan pada strategi penciptaan nilai tidak secara simultan dilaksanakan oleh pesaing saat ini atau masa depan (Porter, 1985).

Barney (1991) juga mendefinisikan keunggulan kompetitif sebagai berikut: "Sebuah perusahaan dikatakan memiliki keunggulan kompetitif yang berkelanjutan ketika sedang melaksanakan strategi yang menciptakan nilai, yang tidak hanya secara simultan dilaksanakan oleh pesaing saat ini atau pihak lain yang berpotensi menjadi pesaing maupun ketika perusahaan lain tidak dapat menduplikasi manfaat dari strategi ini ". Barney juga mengusulkan bahwa, selain menjadi berharga, sumber daya harus memiliki atribut kunci menjadi langka, tidak mudah ditiru, dan tidak bisa digantikan.

Ghemawat dan Rivkin [1999: 49] mengatakan "Bahwa sebuah perusahaan yang menghasilkan keuntungan keuangan yang unggul dalam industrinya (atau kelompok strategis) dalam jangka panjang apabila menikmati keunggulan kompetitif atas para pesaingnya." Dengan demikian, keunggulan kompetitif berarti memiliki rendah biaya, keunggulan diferensiasi, atau strategi fokus yang berhasil.

Keunggulan Kompetitif didefinisikan sebagai keuntungan yang lebih tinggi daripada pesaing, dengan menawarkan nilai lebih besar daripada yang pesaing lakukan kepada konsumen. Keunggulan kompetitif diukur berdasarkan kinerja perusahaan yang komparatif, yang dibandingkan dengan pesaing utama pada area kemampuan yang kompetitif. Keuntungan biaya mengukur kemampuan suatu perusahaan untuk menawarkan layanan harga rendah, sedangkan keuntungan berbagai layanan mengukur kemampuan suatu perusahaan untuk memberikan pelayanan lebih, yang bisa disesuaikan dengan pelanggan (Lai, Zhao, dan Wang, 2007).

Sebagaimana dijelaskan oleh (Narayanan, 2001:247), keunggulan kompetitif perusahaan dapat dicapai melalui pilihan teknologi dalam tiga cara: (1) dengan menekan area bisnis baru dan persaingan, (2) dengan mengubah aturan persaingan dalam bisnis yang ada melalui penyebaran kemampuan teknologi baik dalam rantai produk atau konfigurasi rantai nilai, dan (3) dengan mendukung bisnis yang ada melalui inovasi produk baru dan proses. Teknologi dapat digunakan sebagai senjata yang strategis oleh sejumlah perusahaan-perusahaan kecil untuk mempertahankan daya saing mereka dan mencapai posisi industri yang menguntungkan (Pillania, 2008).

Berdasarkan kajian literatur yang telah dibahas sebelumnya, terdapat beberapa variable yang mempengaruhi seberapa jauh pemanfaatan teknologi informasi terhadap manajemen strategis untuk mendukung strategi kompetitif yaitu: inovasi, R \& D (Penelitian dan Pengembangan), Sumber Daya Teknologi, dan Invenstasi Teknologi.

Walaupun inovasi teknologi bukanlah menjadi jaminan atas pertumbuhan keuangan, penyelarasan strategi teknologi dan strategi perusahaan yang dapat meningkatkan kinerja perusahaan dan 
kompetensi (Chen, 2008). Teknologi inti kompetensi didefinisikan sebagai suatu kombinasi dari keterampilan, pengetahuan dan perilaku yang penting bagi keberhasilan organisasi, kinerja pribadi, dan pengembangan karir. Strategi teknologi dan manajemen teknologi merupakan faktor utama sebagai high return atas inovasi teknologi (Chen, 2008). Inovasi organisasi didefinisikan sebagai organisasi yang memiliki gagasan baru, metode atau perangkat; tindakan untuk menciptakan produk baru atau proses sesuai dengan sesuai dengan Pengembangan Produk dan Management Association (PDMA, 2006). Meskipun pesaing mungkin meniru inovasi teknologi, keuntungan relatif dapat dibuat dan dipertahankan dimana teknologi memanfaatkan beberapa sumber daya penting lainnya. Kettinger et al. (1994) menjelaskan sejumlah sumber daya komplementer tersebut, seperti ukuran, struktur, budaya, dan seterusnya, yang bisa membuat sulit bagi pesaing untuk menyalin atau meniru efek total teknologi. Inovasi dapat terjadi dalam setiap kegiatan penciptaan nilai organisasi, dan segala jenis inovasi, baik teknologi dan non-teknologi, dapat menyebabkan keunggulan kompetitif yang berkelanjutan (AMC, 1995).

Beberapa penelitian tentang $\mathrm{R} \& \mathrm{D}$ mengungkapkan bahwa keterkaitan manajemen puncak strategi bisnis dan teknologi dan memanfaatkan sumber daya eksternal adalah kunci untuk strategi teknologi yang efektif. (Roberts, 2001).

\section{B. Inovasi}

Inovasi adalah implementasi dari produk baru atau secara signifikan meningkatkan (pelayanan yang baik atau), atau proses, metode pemasaran baru, atau metode organisasi baru dalam praktek bisnis, organisasi kerja atau hubungan eksternal (Oslo Manual 2005). Inovasi juga.merupakan produk, layanan atau cara baru dalam melakukan sesuatu dan "mengacu pada setiap barang, jasa, atau ide yang dianggap oleh seseorang sebagai yang baru" (Kotler mengacu Grunert et al., 1997, hal. 4). Inovasi bisa terjadi secara radikal, artinya "yang menyebabkan pemasaran dan teknologi yang tidak berkelanjutan pada kedua tingkat makro dan mikro" - untuk yang tambahan - yang "hanya terjadi pada tingkat mikro dan menyebabkan baik pemasaran atau teknologi yang tidak berkelanjutan tetapi tidak keduanya" (Garcia dan Calantone, 2002, hal. 120). Semakin radikal inovasi, semakin tinggi ketidakpastian dan risiko. Inovasi dapat dihasilkan secara "bottom-up" - pendorong utama menjadi budaya kewirausahaan organisasi - atau "top-down" - pendorong utamanya adalah proses yang terorganisir dan dibuat untuk inovasi. Inovasi juga harus menembus seluruh organisasi, bukan hanya diserahkan kepada ahli Penelitian dan Pengembangan (Deschamps, 2008).

\section{Penelitian Dan Pengembangan}

Penelitian dan Pengembangan ( $R \quad \& \quad D)$ didefinisikan sebagai sebuah upaya kreatif yang dilakukan secara sistematis untuk meningkatkan pengetahuan, termasuk pengetahuan manusia, budaya dan masyarakat dan penggunaan pengetahuan untuk merancang aplikasi baru. Pengertian dari Penelitian dan Pengembangan meliputi tiga kegiatan: penelitian dasar, penelitian terapan dan pengembangan eksperimental. Penelitian Dasar adalah pekerjaan eksperimental atau teoritis yang dilakukan terutama untuk memperoleh pengetahuan baru dari pondasi yang mendasari fenomena dan fakta yang dapat diamati, tanpa aplikasi tertentu atau pandangan tertentu. Penelitian terapan juga penyelidikan asli dilakukan untuk memperoleh pengetahuan baru. Hal ini, bagaimanapun, diarahkan terutama menuju tujuan praktis tertentu atau tujuan. Pengembangan eksperimental adalah kerja yang sistematis, menggambar pada pengetahuan yang ada diperoleh dari penelitian dan / atau pengalaman praktis, yang diarahkan untuk memproduksi bahan-bahan baru, produk atau perangkat, untuk menginstal proses baru, sistem dan layanan, atau untuk meningkatkan secara substansial mereka yang sudah diproduksi atau dipasang.

\section{Sumber Daya Teknologi}

Teknologi adalah kemajuan yang dibuat oleh manusia guna membuat solusi untuk menyelesaikan masalah. Teknologi ini juga memecahkan masalah melalui inovasi dan penciptaan. Sumber daya teknologi adalah sumber daya yang kita butuhkan untuk membantu dalam menyelesaikan pekerjaan. Setiap sistem teknologi memanfaatkan tujuh jenis sumber daya yaitu masyarakat, informasi, bahan, alat dan mesin, energi, modal, dan waktu (Steve Krar, 2014). Teknologi berasal dari kebutuhan masyarakat dan kebutuhan masyarakat mendorong teknologi. Manusia menggunakan apa yang mereka ketahui, mencoba untuk belajar lebih banyak, mendesain dan menciptakan teknologi dengan menggunakan pengetahuan dan kecerdasan mereka. Teknologi membutuhkan informasi untuk memecahkan masalah dan menciptakan pengetahuan baru. Informasi berasal dari data mentah, yang diproses dengan cara mengumpulkan, merekam, mengklasifikasi, menghitung, menyimpan, dan mengambilnya. Informasi dapat ditemukan di banyak tempat: di file komputer, buku, dan lainnya, tapi itu hanya berharga ketika kita memanfaatkannya. Informasi diproses dengan cara dikumpulkan, dipikirkan, dan diterapkan untuk memenuhi kebutuhan dan keinginan. Sumber daya yang ditemukan di alam disebut bahan baku, seperti udara, air, tanah, kayu, mineral, tumbuhan, dan hewan. Bahan sintetis yang diproduksi bahan- 
bahan yang mungkin memiliki karakteristik yang berguna yang tidak dimiliki oleh bahan alami. Manusia telah menggunakan alat untuk menciptakan dunia yang lebih baik untuk diri mereka sendiri selama lebih dari satu juta tahun. Sebagai alat yang baru dikembangkan selama berabad-abad, mereka telah membuat hidup lebih mudah dan lebih baik bagi manusia dan berhak disebut Pencipta Peradaban. Alat terbagi dalam dua kategori; alat yang menggunakan tangan dan alatalat yang menggunakan mesin. Selama ribuan tahun energi berasal dari hewan dan tenaga manusia, kemudian manusia belajar untuk menggunakan angin dan air sebagai sumber energi. Dunia ini menggunakan sejumlah besar energi untuk membuat 3 produk, memindahkan barang dan orang, dan panas, dingin, dan cahaya tempat di mana orang bekerja dan hidup. Sebuah perusahaan membutuhkan modal untuk beroperasi atau memperluas bisnis dan dapat menjual saham di perusahaan kepada orang-orang. Para investor menjadi pemilik bagian (pemegang saham) dalam perusahaan dan mereka berharap bahwa perusahaan akan berhasil sehingga saham mereka akan menjadi lebih berharga. Manusia purba mengukur waktu dengan pengaturan terbit dan matahari dan perubahan musim. Itu jauh kemudian bahwa jam yang digunakan untuk mengukur waktu dalam jam, menit, dan detik. Dalam era industri, waktu menjadi lebih penting karena menetapkan harga pokok produksi.

\section{E. Eksploitasi dan Investasi Teknologi}

Eksploitasi Teknologi merupakan empat upaya yang dilakukan oleh perusahaan untuk membuka koleksi teknologi yang dimiliki oleh perusahaan untuk meningkatkan market value, memanfaatkan aset pelengkap dari mitra industri, mempercepat difusi teknologi untuk desain yang dominan, dan menentukan serta menetapkan standar industri (Khalil, Tarek M., 2000).

Secara umum, sumber daya teknologi perusahaan berasal dari dua bagian yaitu akumulasi teknologi melalui R \& D internal dan kerjasama teknologi eksternal dan pembelian teknologi (Chen, 2008).

Investasi dalam teknologi bagi banyak perusahaan adalah penting. Jika diabaikan, kekurangan dana, atau salah arah, konsekuensi dapat merusak posisi kompetitif perusahaan (Nasierowski, 2005). Nasierowski menyimpulkan makalahnya mengklaim bahwa ada kebutuhan untuk memahami bahwa pengetahuan (teknologi) merupakan aset yang lain, namun itu tidak berwujud, dan harus dikelola secara berbeda dari aset fisik.

Dari uraian diatas, maka variabel yang akan dipakai untuk penelitian selanjutnya antara lain inovasi, peranan Penelitian dan Pengembangan (R
\& D), sumber daya teknologi, eksploitasi dan investasi teknologi, dan korelasi antar variabel. Conceptual framework yang meneliti hubungan pengaruh faktor-faktor yang mempengaruhi keunggulan kompetitif.

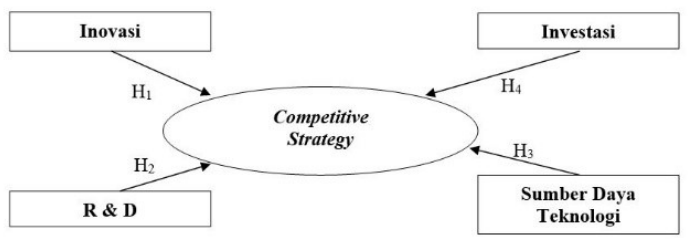

Gambar 1. Model pengaruh Inovasi,

Penelitian dan Pengembangan (R \& D), Sumber Daya Teknologi, Eksploitasi dan Investasi Teknologi terhadap Strategi Kompetitif

Berdasarkan tujuan penelitian, hipotesis berikut akan diuji.

1. Hipotesis 1: Inovasi akan memiliki pengaruh positif signifikan terhadap strategi kompetitif perusahaan.

2. Hipotesis 2: Penelitian dan Pengembangan akan memiliki pengaruh positif signifikan terhadap strategi kompetitif perusahaan

3. Hipotesis 3: Sumber daya teknologi akan berpengaruh positif signifikan terhadap strategi kompetitif perusahaan.

1. Hipotesis 4: Investasi Teknologi akan berpengaruh positif signifikan terhadap strategi kompetitif perusahaan.

\section{Metodologi}

\section{A. Rancangan Penelitian}

Penelitian yang dilakukan ini adalah penelitian dasar dan kausal komparatif, yaitu penelitian untuk mengembangkan teori yang ada dan mengevaluasi konsep-konsep teoritis bukan untuk memecahkan masalah (Indriantoro \& Supomo, 1999), dan memiliki karakteristik masalah berupa hubungan sebab akibat antara dua variabel atau lebih (Indriantoro \& Supomo, 1999).

\section{B. Populasi Dan Sampel Penelitian}

Populasi penelitian adalah perusahaan industri komponen elektronika di Batam dengan total jumlah 129 perusahaan yang berada di sejumlah daerah industri dan galat pendugaan yang digunakan adalah 5\%. Daftar perusahaan industri komponen elektronika per tahun 2019.

Dengan memasukkan angka-angka tersebut ke dalam rumus Slovin di atas, maka didapatkan jumlah sampel minimal yang digunakan adalah $94,073 \approx 94$ sampel. Metode penarikan sampel adalah nonprobability sampling dengan prosedur purposive sampling. Dengan nonprobability sampling, anggota populasi memiliki peluang terpilih yang sama dijadikan sampel. Dengan prosedur purposive sampling ini, pengambilan sampel dilakukan berdasarkan dari jumlah tertentu 
dari populasi dengan menggunakan pertimbangan atau kriteria tertentu (Indriantoro \& Supomo, 1999).

\section{Teknik Pengumpulan Data}

Data yang akan digunakan dalam penelitian ini adalah data primer yang dikumpulkan dengan menggunakan metode penyebaran kuesioner kepada responden. Menurut Bungin (2006), kuesioner merupakan serangkaian atau daftar pernyataan yang disusun secara sistematis. Alasan lain dipilihnya data primer sebagai sumber data dalam penelitian ini adalah data-data tersebut cenderung lebih bersifat opini, sikap, dan pengalaman dari para responden. Pengumpulan data dilakukan dengan membagikan kuesioner kepada perusahaan komponen elektronika yang di Batam. Data yang dibutuhkan dalam penelitian ini adalah kuesioner yang terisi langsung oleh karyawan yang bekerja di perusahaan komponen elektronika di Batam yang memiliki jabatan manajerial dan engineer. Data yang akan dipakai dalam penelitian adalah indikator yang terdapat pada kuesioner dengan syarat telah terisi semua.

\section{Metode Analisis Data}

\section{Uji Hipotesis}

Uji hipotesis bertujuan untuk mengetahui besar kontribusi dan pengaruh masing-masing variabel independen terhadap variabel dependen. Penelitian ini dianalisis dengan menggunakan program SPSS utnuk melihat hasil uji $\mathrm{F}$, uji t, dan uji koefisien determinasi (adjusted $\mathrm{R}^{2}$ ) (Santoso, 2000).

\section{Uji F}

Uji $\mathrm{F}$ digunakan untuk menguji apakah model regresi dapat digunakan untuk memprediksi variabel dependen. Jika angka signifikansi lebih kecil dari 0,05, maka model regresi layak digunakan untuk memprediksi variabel dependen (Ghozali, 2001).

\section{Uji t}

Uji $\mathrm{t}$ digunakan untuk menguji pengaruh masing-masing variabel independen terhadap variabel dependen dalam suatu model penelitian. Jika angka signifikansi lebih kecil dari 0,05 maka

Berdasarkan hasil dari Tabel 1 di atas bahwa Variable (Inovasi, Penelitian dan Pengembangan, Eksploitasi dan Investasi Teknologi, Sumber Daya Teknologi ) memiliki nilai tolerance $>0,10$ ataupun nilai VIF $<10$. Hasil tersebut membuktikan bahwa model regresi yang digunakan dalam penelitian ini tidak ditemukan adanya korelasi antara variabel independen.

\section{Hasil Uji Normalitas}

Uji normalitas pada model regresi bertujuan untuk menguji nilai residual terdistribusi secara variabel independen tersebut berpengaruh signifikan terhadap variabel dependen. Jika angka signifikansi lebih besar atau sama dengan 0,05 maka variabel independen tersebut tidak berpengaruh signifikan terhadap variabel dependen (Ghozali, 2001).

\section{Uji Koefisien Determinasi (Adjusted $\mathbf{R}^{2}$ )}

$\mathrm{Uji}$ adjusted $\mathrm{R}^{2}$ bertujuan untuk mengetahui seberapa besar perubahan variabel dependen yang bisa dijelaskan oleh variabel independen (Santoso, 2000). Uji adjusted $\mathrm{R}^{2}$ dilakukan untuk menunjukkan korelasi antara variabel independen dan variabel dependen apabila angka koefisien determinasi semakin mendekati 1, maka pengaruh variabel independen terhadap variabel dependen adalah semakin kuat, yang berarti variabel-variabel independen memberikan hampir semua informasi yang dibutuhkan untuk memprediksi variasi variabel dependen. Sedangkan nilai Koefisien determinasi (adjusted $\mathrm{R}^{2}$ ) yang kecil berarti kemampuan variabel-variabel independen dalam menjelaskan variasi variabel dependen adalah terbatas (Ghozali, 2001).

\section{Pembahasan}

\section{A. Hasil Uji Asumsi Klasik}

\section{Hasil Uji Multikolinearitas}

Uji Multikolinearitas bertujuan untuk mengetahui apakah didalam model regresi yang dipakai dItemukan adanya korelasi antara variabel independen. Suatu model bebas dari Multikolinieritas apabila nilai Tolerance diatas 0,10 atau nilai Varience Inflation Factor (VIF) dibawah nilai 10 [21].

\begin{tabular}{lllll}
\hline \multicolumn{1}{c}{ Variabel } & \multicolumn{2}{c}{ Collinearity } & Statistics & \multirow{2}{*}{ Kesimpulan } \\
\cline { 2 - 3 } & Tolerance & $\boldsymbol{V I F}$ & \\
\hline Inovasi & $\mathbf{0 . 2 8 3}$ & $\mathbf{3 . 5 2 8}$ & & $\begin{array}{l}\text { Tidak Terjadi } \\
\text { Multikolinieritas }\end{array}$ \\
\hline $\begin{array}{l}\text { Penelitian Dan } \\
\text { Pengembangan }\end{array}$ & $\mathbf{0 . 3 7 0}$ & $\mathbf{2 . 7 0 6}$ & $\begin{array}{l}\text { Tidak Terjadi } \\
\text { Multikolinieritas }\end{array}$ \\
\hline $\begin{array}{l}\text { Sumber Daya } \\
\text { Teknologi }\end{array}$ & $\mathbf{0 . 6 3 3}$ & $\mathbf{1 . 5 7 9}$ & & $\begin{array}{l}\text { Tidak Terjadi } \\
\text { Multikolinieritas }\end{array}$ \\
\hline $\begin{array}{l}\text { Eksploitasi } \\
\text { dan Investasi } \\
\text { Teknologi }\end{array}$ & $\mathbf{0 . 6 9 8}$ & $\mathbf{1 . 4 3 2}$ & & $\begin{array}{l}\text { Tidak Terjadi } \\
\text { Multikolinieritas }\end{array}$ \\
\end{tabular}

normal atau tidak antara variabel dependen dan variabel independen atau keduanya. Model regresi yang baik adalah memiliki nilai residual yang terdistribusi secara normal atau mendekati normal. Uji normalitas dilakukan untuk menentukan apakah data yang diperoleh memiliki distribusi normal atau tidak. 


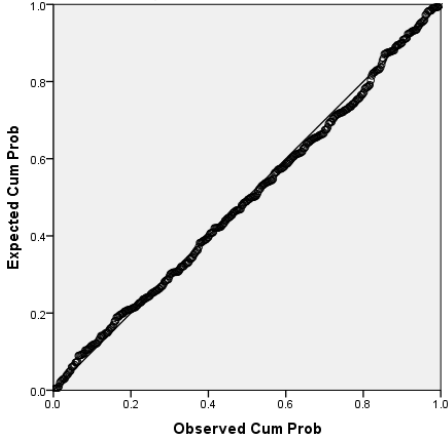

Gambar 2. Hasil Uji Normalitas

Gambar 2 menunjukkan bahwa data menyebar di sekitar garis diagonal. Dengan demikian dapat disimpulkan bahwa data yang diperoleh terdistribusi dengan normal.

\section{Hasil Uji Heteroskedastisitas}

Uji heteroskedastisitas bertujuan untuk melihat apakah variabel pengganggu mempunyai varian yang sama atau tidak. Heteroskedastisitas menggambarkan keadaan suatu varian dari variabel pengamatan ke pengamatan yang lain.

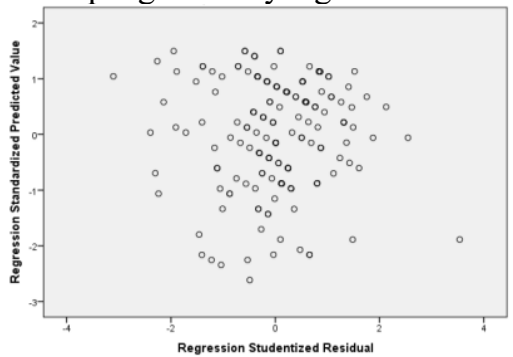

Gambar 3. Hasil Uji Heteroskedastisitas

Berdasarkan hasil uji heteroskedastisitas pada gambar 3 di atas dapat dilihat bahwa grafik scatterplot terlihat bahwa titik-titik menyebar secara acak serta tersebar secara baik diatas dan dibawah angka 0 (nol) pada

sumbu Y. Hal ini dapat disimpulkan bahwa tidak terjadi heteroskedastisitas pada model regresi, sehingga model regresi layak dipakai untuk memprediksi Inovasi, Penelitian Dan Pengembangan, Sumber Daya Teknologi, Eksploitasi dan Investasi Teknologi Terhadap Strategi Kompetitif Perusahaan.

\section{B. Uji Hipotesis}

Pengujian Hipotesis menggunakan regresi berganda yaitu digunakan untuk menganalisis hubungan antara Inovasi, Penelitian Dan Pengembangan, Sumber Daya Teknologi, Eksploitasi dan Investasi Teknologi Terhadap Strategi Kompetitif Perusahaan. Penulis menggunakan bantuan program SPSS Versi 21 untuk pegujian Hipotesis.

\section{Uji F}

Uji F digunakan untuk menunjukkan apakah seluruh variabel independen berpengaruh terhadap variabel dependen. Cara uji $\mathrm{F}$ adalah dengan melihat hasil signifikan dimana probabilitas $<0,05$, maka hasil dari pengujian berpengaruh terhadap variabel dependen, jika probabilitas $>0,05$ maka hasil dari pengujian tidak berpengaruh terhadap variabel dependen. Hasil uji F pada Tabel 2 menunjukkan angka signifikan sebesar $0,000^{3}$. Dengan tingkat signifikan sebesar $0,000^{3}$ lebih kecil dari 0,05, maka Inovasi, Penelitian Dan Pengembangan, Sumber Daya Teknologi, Eksploitasi dan Investasi Teknologi mempunyai pengaruh secara simultan terhadap Strategi Kompetitif Perusahaan.

Tabel 2. Hasil Uji F Inovasi, Penelitian Dan Pengembangan, Sumber Daya Teknologi, Eksploitasi dan Investasi Teknologi Terhadap Strategi Kompetitif Perusahaan

\begin{tabular}{cccc}
\hline Model & F & Sig. & Keterangan \\
\hline Regression & 154.736 & $\mathbf{0 , 0 0 0}^{\mathbf{b}}$ & Signifikan
\end{tabular}

\section{Uji T}

Uji T digunakan untuk menunjukkan seberapa jauh pengaruh variabel independen secara individual dalam menerangkan variabel dependen. Cara uji $\mathrm{T}$ adalah dengan melihat hasil signifikan dimana probabilitas $<0,05$ berarti hasil dari pengujian adalah signifikan.

Berdasarkan hasil Uji $\mathrm{T}$ pada Tabel 3 di atas, menunjukkan bahwa signifikan Inovasi adalah 0,000 atau nilai probabilitas berada dibawah 0,05 , maka H1 diterima. Signifikan Penelitian Dan Pengembangan adalah $\mathbf{0 , 0 0 0}$ atau nilai probabilitas berada dibawah 0,05, maka H2 diterima. Signifikan
Sumber Daya Teknologi adalah 0,000 atau nilai probabilitas berada dibawah 0,05, maka H3 diterima. Signifikan Eksploitasi Dan Investasi Teknologi adalah $\mathbf{0 , 0 0 0}$ atau nilai probabilitas berada dibawah 0,05 , maka $\mathrm{H} 4$ diterima.

Dari hasil pengolahan data, terlihat bahwa Inovasi, Penelitian Dan Pengembangan, Sumber Daya Teknologi, Eksploitasi Dan Investasi Teknologi berpengaruh terhadap Strategi Kompetitif Perusahaan.

\section{3. $\mathbf{U j i} \mathbf{R}^{2}$}


Uji koefisien determinasi $\left(\mathrm{R}^{2}\right)$ digunakan untuk mengukur sejauh mana kemampuan model dalam menerangkan variasi variabel dependen (Strategi Kompetitif Perusahaan). Nilai koefisien determinasi berada antara 0 dan 1 . Jika nilai $\mathrm{R}^{2}$ kecil artinya kemampuan variabel independen untuk menjelaskan variasi variabel dependen sangat terbatas. Sedangkan jika nilai $\mathrm{R}^{2}$ mendekati satu, maka variabel independen dapat memberikan hampir seluruh informasi yang dibutuhkan untuk memprediksi variasi variabel dependen [21].
Berdasarkan hasil uji $\mathrm{R}^{2}$ pada Tabel 4 diperoleh nilai adjusted $\mathrm{R}^{2}$ sebesar $\mathbf{0 . 6 6 9}$ berarti $\mathbf{6 6 . 9 \%}$ variabel Strategi Kompetitif Perusahaan dijelaskan oleh Inovasi, Penelitian Dan Pengembangan, Sumber Daya Teknologi, Eksploitasi Dan Investasi Teknologi sebagai variabel independen. Sedangkan sisanya 33.1\% $(100 \%-66.9 \%=33.1 \%)$ dijelaskan oleh sebab-sebab lain diluar model. Sedangkan nilai Standard Error of Estimate sebesar 3.182 berarti tingkat kesalahan penafsiran dari regresi adalah sebesar 3.182.

Tabel 3. Hasil Uji T Inovasi, Penelitian Dan Pengembangan, Sumber Daya Teknologi, Eksploitasi dan Investasi Teknologi Terhadap Strategi Kompetitif Perusahaan

Variabel
Unstandardized

Coefficients $\mathrm{t}$

Sig.
Keterangan

B Std. Error

\begin{tabular}{lrrrrr}
\hline Konstanta & - & .916 & - & .000 & \\
& 3.843 & & 4.195 & & \\
\hline Inovasi & .513 & .077 & 6.678 & .000 & H1 Signifikan \\
\hline Penelitian Dan Pengembangan & .256 & .053 & 4.836 & .000 & H2 Signifikan \\
\hline Sumber Daya Teknologi & .229 & .049 & 4.695 & .000 & H3 Signifikan \\
\hline Eksploitasi dan Investasi Teknologi & .217 & .048 & 4.556 & .000 & H4 Signifikan \\
\hline
\end{tabular}

Tabel 4. Hasil Uji $\mathbf{R}^{2}$ Inovasi, Penelitian Dan Pengembangan, Sumber Daya Teknologi, Eksploitasi dan Investasi Teknologi Terhadap Strategi Kompetitif Perusahaan MODEL ADJUSTED R SOUARE STD. ERROR OF THE ESTIMATE 0.669 3.182

\section{Kesimpulan}

\section{A. Kesimpulan}

Berdasarkan uraian dan analisis pembahasan di atas maka dapat disimpulkan sebagai berikut :

1. Hasil pengujian pada Hipotesis Pertama (H1) dengan regresi berganda menyatakan bahwa Inovasi berpengaruh terhadap Strategi Kompetitif Perusahaan. Hasil penelitian ini mendukung dengan hasil penelitian dengan hasil penelitian Ergin dan Ergin dan Akbay (2010); Choy dan Ng (2011); Shaharudin et.al. (2011); Chi, Yeh, dan Yang (2009); Vidyarthi dan Dash (2010); serta Yaseen et.al. (2011).

2. Hasil pengujian pada Hipotesis Kedua (H2) dengan regresi berganda menyatakan bahwa Penelitian Dan Pengembangan berpengaruh terhadap Strategi Kompetitif Perusahaan. Hasil penelitian ini mendukung dengan hasil penelitian Ergin dan Akbay (2010); Vidyarthi dan Dash (2010); Bao dan Mandrick (2004); Akram dan Merunka (2010); serta Teah dan Phau (2008).

3. Hasil pengujian pada Hipotesis Ketiga (H3) dengan regresi berganda menyatakan bahwa Sumber Daya Teknologi berpengaruh terhadap
Strategi Kompetitif Perusahaan. Hasil penelitian ini mendukung dengan hasil penelitian Ergin dan Akbay (2010); Choy dan Ng (2011); Wong et.al. (2007); Shaharudin et.al. (2010); serta Kuo, Wu, dan Deng (2009).

4. Hasil pengujian pada Hipotesis Keempat (H4) dengan regresi berganda menyatakan bahwa Eksploitasi dan Investasi Teknologi berpengaruh terhadap Strategi Kompetitif Perusahaan. Hasil penelitian ini mendukung dengan hasil Chi, Yeh, dan Yang (2009); Yaseen et.al. (2011); Shabbir et.al. (2009); Gilaninia dan Abbaszadeh (2011); serta Hanzee dan Yazd (2010).

\section{B. Keterbatasan}

Dalam melakukan penelitian ini terdapat beberapa keterbatasan yang mengakibatkan kurang sempurnanya penelitian ini yaitu sebagai berikut:

1. Penelitian ini hanya menggunakan variabel Inovasi, Penelitian Dan Pengembangan, Sumber Daya Teknologi, Eksploitasi Dan Investasi Teknologi, sehingga masih terdapat variabel lain yang dapat menjelaskan variabel Strategi Kompetitif Perusahaan. 
2. Populasi responden yang digunakan dalam penelitian ini adalah pada perusahaan industri komponen elektronika di Batam.

\section{Rekomendasi}

Penulis dapat menuliskan rekomendasi yang dapat dijadikan sebagai bahan pertimbangan untuk peneliti selanjutnya karena keterbatasan waktu dan biaya pada penelitian ini. Penulis mengharapkan untuk peneliti selanjutnya dapat mempertimbangkan:

1. Untuk penelitian selanjutnya direkomendasikan agar peneliti lebih banyak meluangkan waktu dan biaya pada penelitian tersebut dan agar banyak mencari informasi mengenai objek penelitian ini.

2. Penelitian selanjutnya diharapkan dapat menambahkan variabel lain selain Inovasi, Penelitian Dan Pengembangan, Sumber Daya Teknologi, Eksploitasi Dan Investasi Teknologi untuk dapat mengembangkan penelitian ini. Misalnya Perceived Risk menurut Choy, Ng, dan Ch'ng (2011) dan Brand Image menurut Lin (2010).

3. Kepada perusahaan, agar dapat lebih memperhatikan Sumber Daya Teknologi, Eksploitasi Dan Investasi Teknologi.

\section{DAFTAR PUSTAKA}

[1] http://www.Vivanews.co.id, diakses tanggal 19 Juni 2018, pukul 18.15 WIB.

[2] http://www. Gartner.com, diakses tanggal 19 Juni 2018, pukul 18.25 WIB.

[3] Porter, M.E. (1985). Competitive Advantage : Creating and Sustaining Superior Performance : with a new introduction. The Free Press. New York, USA.

[4] Barney, J. B., (1991). Firm resources and sustained competitive advantage, Journal of Management, Vol. 17, pp.99-120.

[5] Ghemawat, Pankaj, and Jan W. Rivkin. (1998). "Creating Competitive Advantage." Harvard Business School Background Note 798-062, January 1998. (Revised February 2006).

[6] Zhou, Q.; Jhon Z. Wen; Pei Zhao; dan William A.A.: Synthesis of Vertically-Aligned Zinc Oxide Nanowires and Their Application as a Photocatalyst. Nanomaterials 2017,7(9).

[7] Ambiga, S., Narayanan R., Gowri, D., Sukumar, D., dan Madhavan, S., 2007, Evaluation of Wound Healing Activity of
Flavonoids from Ipomoea carnea Jacq., Ancient Science of Life, 26(3) : 45-51.

[8] http://www. Ekonomi.inilah.com, diakses tanggal 19 Juni 2018, pukul 19.15 WIB.

[9] http://www.gosocio.co.id, diakses tanggal 19 Juni 2018, pukul 20.11 WIB.

[10] http://www.detik.com, diakses tanggal 19 Juni 2018, pukul 21.35 WIB.

[11] Chen, Q, dan W. D. Wells. 1999. Attitude Toward the Site. Journal of Advertising Research 39, no. 5: 27-37.

[12] Kettinger, W. J., \& Choong C. Lee. (1994). "Perceived Service Quality and User Satisfaction with the Information Services Function", Decision Sciences, vol. 25 (5/6), hal. 737-766.

[13] OECD/Eurostat. (2005). Oslo Manual: Guidelines For Collecting and Interpreting Innovation Data (Third Edition). Paris: OECD.

[14] Kohler, C., Sofka W. dan Grimpe C. (2012). Selective Search, Sectoral Patterns, and The Impact on Product Innovation Performance. Research Policy, (41), pp. 1344-1356

[15] Katz, R. dan Allen, T. J. (1982) An Emiprical Test of The Not Invented Here (NIH) Syndrome: A Look at The Performance Tenure, and Communication Pattern of R\&D Project Groups. R\&D Management, 12 (1), pp. 7-20.

[16] Krar .Steve, Arthur Gill, Peter Smid. (2003). "Machine Tool Technology Basics" Industrial Press Inc. United State Of America. New York.

[17] Khalil, Tarek M. (2000). Management of Technology The Key to Competitiveness and Wealth Creation. Singapore: McGraw-Hill.

[18] Indriantoro, nurdan Supomo, bambang. (1999). Metodologi Penelitian Bisnis Untuk. Akuntansi \& Manajemen. Yogyakarta : Penerbit BPFE.

[19] Bungin, Burhan. (2006). Analisis Data Penelitian Kualitatif. Jakarta : Raja Grafindo.

[20] Santoso, Singgih. (2000). Buku Latihan SPSS: Statistik Parametrik. Jakarta: ELex. Media Komputindo.

[21] Ghozali, Imam. (2001). Aplikasi Analisis dengan Program SPSS. Undip: Semarang. 